\title{
Trials on the Timing of Chemical Control of Lentil weevil, Bruchus lentis Frölich (Coleoptera: Chrysomelidae: Bruchinae) in Lentil Field in Gachsaran Region (Iran)
}

\author{
K. Saeidi, ${ }^{1}$ S. Mirfakhraie ${ }^{2}$ \\ ${ }^{1}$ Plant Protection Research Department, Fars Agricultural and Natural Resources Research and Education Center, \\ AREEO, Shiraz; ${ }^{2}$ Plant Protection Department, Faculty of Agriculture, Urmia University, Urmia, Iran
}

\begin{abstract}
The lentil weevil, Bruchus lentis Frölich, (Coleoptera: Chrysomelidae: Bruchinae) is the most serious pest of lentil in Iran. Economic losses due to this pest reach up to $40 \%$ of the lentil crop. Over a two-year study (2012 and 2013) in Agricultural Research Station of Gachsaran Region, best timing of chemical control of $B$. lentis was determined. A field experiment with cultivation of lentil Sina variety Lens culinaris Medik was conducted in a randomized complete block design with five treatments and three replications. The treatments consisted of spraying four times (respectively, during the early flowering, 10 days after the first spraying, 10 days after the second spraying; 10 days after the third spraying) and control (without spraying). For the spraying from Endosulfan insecticide EC50\% at ratio one liter per hectare was used. Three samples were taken from the pods and totally 150 pods from each replicate for contaminations of seeds were investigated. After the determination of the percent of seeds contamination, results were statistically analysed. Based on the results obtained, first spray treatment, with the mean contamination of
\end{abstract}

\footnotetext{
Correspondence: Karim Saeidi, Plant Protection Research Department, Fars Agricultural and Natural Resources Research and Education Center, AREEO, Shiraz, Iran.

Tel.: +98.71.32622431 - Fax: +98.71.32623470.

E-mail: saeidi391@yahoo.com
}

Key words: Chemical control, Lentil Seed Beetle, Gachsaran Iran.

Conflict of interest: the author declares no potential conflict of interest.

Received for publication: 2 June 2017.

Revision received: 27 June 2017.

Accepted for publication: 28 June 2017.

CCopyright K. Saeidi and S. Mirfakhraie, 2017

Licensee PAGEPress, Italy

Journal of Entomological and Acarological Research 2017; 49:6829 doi:10.4081/jear:2017.6829

This article is distributed under the terms of the Creative Commons Attribution Noncommercial License (by-nc 4.0) which permits any noncommercial use, distribution, and reproduction in any medium, provided the original author(s) and source are credited.
$15.45 \%$ and second spray treatment with the mean contamination of $12.25 \%$ had the highest impact on reducing contamination lentil seeds to $B$. lentis and between them there was no statistically significant difference and were in one group. Therefore, spraying one time during the early flowering until 15 days after it was the best time to control of $B$. lentis.

\section{Introduction}

Plants of genus Lens Miller include six species: Lens culinaris Medikus, L. tomentosus Ladiz., L. odemensis Ladiz., L. ervoides (Brign) Grande, L. nigricans (M. Bieb) Godr. and L. lamottei Cezfr. Two subspecies are included in L. culinaris: the cultivated lentil $L$. culinaris subsp. culinaris, and the putative ancestor of the crop, $L$. culinaris subsp. orientalis (Boiss) (Cokkizgin \& Shtaya, 2013).

Due to its protein and fiber contents, lentil is a worldwide food legume used in the human diet and livestock feed (Bhatty, 1987). This herbaceous plant needs very low agronomic inputs and it is frequently used in crop rotations because of its nitrogen fixing capacity (Bicer \& Sakar, 2010). Lentil, an important leguminous crop, is the cheap source of protein in most countries including Iran (Good, 2000). All of these facts provide this crop with a huge potential in a climate changing world, rationing water for agriculture, elevating prices for fertilizers, and increasing demand for secure and available highly nutritional products (Kara, 2006).

The area under lentil cultivation is about 300,000 hectares in Iran with an average annual production of 160,000 tons (Center of Statistics of Ministry of Agriculture Iran, 2013). This size of cultivation has been promoted due to the policies set by the Iranian Ministry of Agriculture. Hence, the province of Kohgiluyeh va Boyerahmad increased the cultivation area from 4500 hectares in the farming year of 2008 to 6350 hectares in the farming year of 2012 (Ministry of Agriculture Iran, 2013). The increase in cultivation area prepares the situation for harmful activities of pests, diseases, weeds and finally crop damage and yield decrement (Ahlawat et al., 1991; Isman, 2006; Gulati, 2007; Saeidi \& Hassanpour, 2014).

Bruchids belonging to genus Bruchus (Coleoptera: Chrysomelidae: Bruchinae) are the most damaging pests of lentil crop as seed weevils (Malik \& Saxena, 1992). Bruchus lentis Frölich is one of the most important pests causing serious damages to lentil in Iran and around the world (Campbell \& Runnion, 2003). They appear in high population in fields and storages in 
central and western Europe (Gorham, 2010), Mediterranean coasts (Good, 2000) and Iran (in the provinces of east- Azerbaijan, westAzerbaijan, Hamedan, Ghazvin, Tehran, Isfahan and Fars) (Taghizadeh-Saroukolahi \& Meshkatalsadat, 2010). Currently, this is a major pest of lentil in Iran (Taghizadeh-Saroukolahi \& Meshkatalsadat, 2010). In Gachsaran, the warm regions of Kohgiluyeh va Boyerahmad, B. lentis have been reported by for the first time in 1998 (Saeidi, 1999). It is known as the main pest of lentil in this province and one of the most important insect threats to stored grains. It is cosmopolitan and also a serious pest of peas, cowpeas, cotton seed, sorghum and maize (Aydogan et al., 2003). Bruchid larvae cause major losses of grain legume crops throughout the world. Some bruchid species, such as the cowpea weevil (Callosobruchus maculatus F.) and bean weevil (Acanthoscelides obtectus Latr.), are pests that damage stored seeds. Others, such as the pea weevil [Bruchus pisorum (L.)], attack the crop growing in the field (Shade et al., 2010). Both larvae and beetles are responsible for causing the damage (Polanco \& Rennie, 2004; Bhal et al., 2008). Duke \& Yadav (2000) reported $30-60 \%$ loss in seed weight and $40-65 \%$ loss in protein content due to its damage and pulse seeds become out of shape for human consumption as well as for planting (Rehman et al., 1992; Polanco \& Rennie, 1995; Shahab-Ghayoor \& Saeidi, 2015).

Synthetic pesticides have been considered one of the most effective and accessible means of controlling insect pests of stored products (Raghuvanshi \& Singh, 2008). The use of chemicals is associated with undesirable effects on the environment due to their slow biodegradation and some toxic residues in products, affecting mammalian health (Benhalima et al., 2004; Bhatty, 1987; Halder et al., 2010). Nevertheless, this method has some drawbacks like infested lentils are no longer suitable for human consumption (FAO, 2014), and their germination capacity may be reduced up to $45 \%$ (Smith \& Turan, 2006). Literature concerning method to control this pest is scarce and only refers to phenological escape in some Culinaris culinaris L. varieties (Duke \& Yadav, 2000). Unfortunately, no comprehensive and useful information about lentil pests in Kohgiluyeh va Boyerahmad province and other parts of the Iran can be found. Therefore, the main goal of the present study was determination of the best timing in chemical control of $B$. lentis.

\section{Materials and Methods}

An experiment was conducted on an established lentil genotype namely Sina and five treatments, spraying at early pod appearance; fifteen days after the first spraying; fifteen days after the second spraying; fifteen days after third spraying and control treatment.

For the spraying from Endosulfan $\left(\right.$ Thiodan $^{\circledR}$ ) insecticide EC50\% at ratio one liter per hectare was used. These insecticides were obtained from the local market. Before each spray, the volume of spray solution was calibrated by spraying measured volume of water on the check plots. Ten litters hand operated Knapsack sprayer was used for the application of insecticide.

These five treatments were arranged in a randomized complete block design with three replications on fifteen plots. Each plot with a size of $2 \times 10$ square meters have ten rows so that at the time of harvest six rows in the middle from each plot were selected for each treatment. Distance between each plot was kept as $10 \mathrm{~m}$. All other agronomic practices were applied equally in all methods. Information on different factors was recorded and analysed statistically by Fishers analysis of variance. Seed damage and yield per plot in different treatments were compared by using Least Significance Difference (LSD) test at 5\%.

\section{Results}

Analysis of variance in the seed characters revealed that there was a significant difference in weight of one thousand seeds, percentage of protein, percentage of damage and harvest/ha among five different treatments, at $\mathrm{P}<0.05$ (Table 1). The Coefficient of Variation (CV) was recorded for weight of one thousand seeds, percentage of protein, percentage of damage and harvest/ha as 4.5, $1.48,1.55$ and 0.43 , respectively.

\section{Percentage damage (parameter used for damage evaluation)}

The lentil damages indices in the experimental blocks at each stage of plant development were determined. For this purpose, the number of healthy and contaminated cocoons per plant in each block was counted and recorded. The obtained data were used to determine the percentage of lentil seed in each treatment. Percentage damage of lentil seed was significantly different among the various treatments tested for lentil weevil control. The highest seed damage of $39.4 \%$ was observed in case of lentil plants where no treatment was adopted. The lowest damage of 5\% of lentil plants was recorded where fifteen days after the first spraying were carried out. This treatment had a significant difference with spraying at early pod appearance in which $8 \%$ damage was recorded (Table 2).

\section{Harvest}

Seed yield differs significantly among varied treatments of lentil weevil control. Fifteen days after the first spraying produced a significantly highest harvest of $1850 \mathrm{~kg} / \mathrm{ha}$ followed by spraying at early pod appearance treatment, which gave a harvest of 1723 $\mathrm{kg} / \mathrm{ha}$ (Table 2). The lowest harvest of $1103 \mathrm{~kg} / \mathrm{ha}$ was recorded in case of plants where no treatment was applied. With respect to the most important measure from commercial perspectives, the amount of harvest, the control method (no measure taken) was recognized as the least productive. Therefore, the necessity of adopting the most appropriate method of controlling lentil weevils is a need which will determine the profitability of cultivating lentil.

\section{Weight of one thousand seeds}

Weight lentil was significantly different among the various treatments tested for lentil weevil control. The minimum weight of one thousands seeds 22.6 (gr) was observed in case of lentil plants

Table 1. Means squares of ANOVA for all traits.

\begin{tabular}{|c|c|c|c|c|c|}
\hline ANOVA & Df & Weight 1000 seeds (gr) & $\%$ protein & $\%$ damage & Harvest (kg/ha) \\
\hline Block & 2 & 0.20 & 1.61 & 3.20 & 1265.40 \\
\hline Treatment & 3 & 33.85 & 35.80 & 556.32 & 254306.56 \\
\hline Error & 6 & 1.43 & 0.17 & 0.70 & 43.317 \\
\hline
\end{tabular}


Table 2. Comparison of different time to chemical control lentil weevil, Bruchus lentis on Lentil.

\begin{tabular}{lcccc} 
Treatments & Weight 1000 seeds (in gr) & \% protein & \% damage & Harvest (kg/ha) \\
Control & $22.6000^{c}$ & $24.5667^{\mathrm{c}}$ & $39.4333^{\mathrm{a}}$ & $1103.000^{\mathrm{e}}$ \\
Spraying at early pod appearance & $29.2667^{\mathrm{a}}$ & $28.3000^{\mathrm{b}}$ & $8.0000^{\mathrm{d}}$ & $1723.333^{\mathrm{b}}$ \\
\hline 15 days after the third spraying & $26.3333^{\mathrm{b}}$ & $25.1500^{\mathrm{c}}$ & $20.0000^{\mathrm{b}}$ & $1405.000^{\mathrm{d}}$ \\
15 days after the second spraying & $24.000^{\mathrm{c}}$ & $28.2333^{\mathrm{b}}$ & $14.0000^{\mathrm{c}}$ & $1566.667^{\mathrm{c}}$ \\
\hline 15 days after the first spraying & $30.5000^{\mathrm{a}}$ & $33.2667^{\mathrm{a}}$ & $5.1667^{\mathrm{e}}$ & $1850.000^{\mathrm{a}}$ \\
LSD value $(0.05)$ & 22.556 & 0.7828 & 0.5076 & 12.392 \\
\hline
\end{tabular}

Means with at least a common letter significant, in the ANOVAs test at $5 \%$ level have significant difference.

where no control measure was adopted. The maximum weight of one thousands seeds 30.5 (gr) was recorded in the case where fifteen days after the first spraying practices were carried out. Fifteen days after the first spraying had a non-significant difference with spraying at early pod appearance control method in which 29.2 (gr) were recorded. Among the four time compared to the control case, the fifteen days after the second spraying was observed to be the least successful method with respect to the measure of one thousands seeds weight (Table 2).

\section{Percentage of protein}

Percentage protein of lentil seed was significantly different among the various treatments tested for lentil weevil control. The lowest percentage protein seed of $24.56 \%$ was observed in case of lentil plants where no control measure was adopted. The highest percentage of protein seed of $33.26 \%$ was recorded in case of lentil plants in which fifteen days after the first spraying practices were carried out. Fifteen days after the first spraying had significant differences with spraying at early pod appearance treatment in which $28.3 \%$ were recorded. In case of the measure of percentage of protein, the fifteen days after the second spraying treatment was found to be as successful as the insecticide method. However, with the exception of the fifteen days after the first spraying treatment, the other treatments compared to the control treatment were found roughly yielding close results although statistically different.

\section{Discussion and Conclusions}

In the current research, the researcher has compared four treatments to control the lentil weevil (spraying at early pod appearance; fifteen days after the first spraying; fifteen days after the second spraying; fifteen days after third spraying and control treatment). The four treatments were then compared in four established measures (weight of one thousands seeds, percentage of protein, percentage of damage, and harvest). Results revealed that the fifteen days after the first spraying treatment among other treatments was significantly more successful in all the four measures. The means achieved for the fifteen days after the first spraying with respect to the measures of harvest $(\mathrm{kg} / \mathrm{ha})$ and percentage of protein were observed economically prosperous. Furthermore, the fifteen days after the first spraying treatment, based on the results achieved, revealed to be ecologically promising. The fifteen days after the first spraying treatment can be used as a safe insecticidal to the environment. It builds better conditions for growth of plant and could decrease pest population and damage; hence, it can increase crop harvest.

The present study confirmed the efficacy of Endosulfan insec- ticide against lentil seed beetle, $B$. lentis in Iran. New products are introduced to the market which need close monitoring and evaluation. The present study was such an effort in determining the best time for control of lentil seed beetle, B. lentis. The present studies also revealed that Endosulfan insecticide were effective in controlling the pest.

\section{References}

AHLAWAT K., KHALIQUE I., KHAN A., AFZAL M., MALIK B.A., 1991 - Studies on genetic resistance in chickpea (Cicer arietimum L.) to bruchid beetle (Callosobruchus chinensis L.) attack. - Pak. J. Sci. Industr. Res. 34: 449-452.

AYDOGAN K., ITINO S., ICHIKAWA T., 2003 - Duration of developmental stages of Bruchus lentis (Coleoptera: Bruchidae) on Azuki bean and the effects of neem and sesame oils at different stages of their development. - Pak. J. Biol. Sci. 6: $932-935$.

BAHL F.S., AVERBECK D., AVERBECK B., IDAOMAR M., 2008 - Biological effects of essential oils a review. - Food Chem. Toxicol. 46: 446-475.

BENHALIMA H., CHAUDHRY M.Q., MILLS K.A., PRICE N.R., 2004 - Phosphine resistance in stored-product insects collected from various grain storage facilities in Morocco. - J. Stored Prod. Res. 40: 241-249.

BHATTY R.S., 1987 - Composition and quality of lentil (Lens culinaris Medik.). A review. Canadian Inst Food Sci Tech J. 21: 144-160.

BICER B.T., SAKAR D., 2010 - Heritability of yield and its components in lentil (Lens culinaris Medik.). - Bulgar. J. Agricult. Sci. 16: 30-35.

CAMPBELL F., RUNNION C., 2003 - Patch exploitation by female lentil weevil, Bruchus lentis. - J. Insect Sci. 3: 89-98.

CENTER OF STATISTICS OF MINISRY OF AGRICULTURE IRAN, 2013 - Agriculture - statistics. Available from: https:/www.amar.org.ir/english/Statistics-by-Topic/Agriculture

COKKIZGIN A., SHTAYA M.J.Y., 2013 - Lentil: origin, cultivation techniques, utilization and advances in transformation. Agricult. Sci. 1: 55-62.

DUKE G.T., YADAV T.D., 2000 - Feeding of Callosobruchus maculatus (Fab.) and Callosobruchus chinensis L. in green gram. - Indian J. Entomol. 40: 108-112.

F.A.O. 2014. Annotated list of Guidelines for the implementation of the International Code of Conduct on Pesticide Management. Available from: http://www.fao.org/fileadmin/ templates/agphome/documents/Pests_Pesticides/Code/Annota ted_Guidelines2014.pdf 
GOOD N.E., 2000 - The seed beetles of the genus Bruchus. USDA Technical Bulletin. 5: 27-28. GORHAM R.J. 2010. - Insect and mite pests in food. USDA Agriculture. Washington, WA. USA.

GORHAM R.J., 2010 - Insect and mite pests in food. USDA Agriculture. - Washington, WA. USA.

GULATI R., 2007 - Potential of garlic as grain protectants against Tyrophagus putrescentiae and Suidasia nesbitti in wheat. System. Appl. Acarol. 12: 19-25.

HALDER J., SRIVASTAVA C., DUREJA P., 2010 - Effect of methanolic extracts of periwinkle (Vinca rosea) and bottlebrush (Callistemon lanceolatus) alone and their mixtures against neonate larvae of gram pod borer (Helicoverpa armigera). - Indian J. Agricult. Sci. 80: 820-823.

ISMAN M.B., 2006 - Botanical insecticide deterrents in modern agriculture and increasingly regulated world. Ann. Rev. Entomol. 5:45-66.

KARA M.B., 2006 - Botanical insecticides, deterrents, and repellents in modern agriculture and an increasingly regulated world. - Ann. Rev. Entomol. 51: 45-66.

MALIK K.A., SAXENA P.K., 1992 - Thidiazuron induces high frequency shoot regeneration in intact seedlings of pea (Pisum sativum), chickpea (Cicer arietinum) and lentil (Lens culinaris). - Austral. J. Plant Physiol. 19: 731-740.

POLANCO I., RENNIE M., 1995 - Evaluation of certain spices for the control of Callosobruchus maculatus (Fabricius) (Coleoptera: Bruchidae) in cowpea seeds. - Afr. J. Entomol. 3: 87-89.

POLANCO I., RENNIE M., 2004 - Evaluation of certain spices for the control of Callosobruchus maculatus (Fabricius) (Coleoptera: Bruchidae) in cowpea seeds. - Afr. J. Entomol. 3: 87-89.
RAGHUVANSHI S., SINGH V., 2008 - Plant products as fumigants for stored - product insect control. - J. Stored Prod. Res. 44: 126-135.

REHMAN M., MOHAMMAD H., AHMED F., MANAS A., SKARI M., 1992 - Screening of tropical plants for the presence of bioactive compounds. - Pertanika J. Trop. Agric. Sci. 15: 131-135.

SAEIDI K., 1999 - Investigation on the timing of chemical control of lentil weevil, bruchus lentis (Coleoptera: Bruchidae) in lentil fields in Gachsaran region. - Final Report, Agricultural and Natural Research Centre of Yasouj. Yasouj, Iran. 45p.

SAEIDI K., HASSANPOUR B., 2014 - Efficiency of Mentha piperita L. and Mentha pulegium L. Essential oils on nutritional indices of Plodia interpunctella Hubner (Lepidoptera:Pyralidae). - J. Entomol. Acarol. Res.. 46: 13-17.

SHADE H., MRIG K., MAHLA J.C., 2010 - Effect of different plant products on the fecundity and emergence of lesser grain beetle, Bruchus lentis (Fab.) in wheat grains. - Ann. Biol. Ludhiana. 12: 96-98.

SHAHAB-GHAYOOR H., SAEIDI K., 2015 - Antifeedant activities of essential oils of Satureja hortensis and Fumaria parviflora a gainst Indian Meal Moth, Plodia interpunctella Hubner (Lepidoptera: Pyralidae). - Entomol. Ornithol. Herpetol. 4:1-4.

SMITH D.K., TURAN T.D., 2006 - Inhibition of sterol $4 \alpha$-methyl oxidase is the principal mechanism by which garlic decreases cholesterol synthesis. - J. Nutr. 136: 759-805.

TAGHIZADEH-SAROUKOLAI A., MESHKATALSADAT M.S., 2010 - Insecticidal properties of Thymus parsecs essential oil against Tribolium castaneum and Sitophilus oryzae. - J. Pest Sci. 83: 3-8. 